\title{
Oncogene ERB A
}

National Cancer Institute

\section{Source}

National Cancer Institute. Oncogene ERB A. NCI Thesaurus. Code C17758.

Two ERBA proto-oncogenes located on separate chromosomes, encode ERBA alpha and ERBA beta, which are thyroid hormone receptors in the nucleus and bind DNA to activate transcription. Multiple thyroid hormone receptor (THR) genes may be encoded in the human genome and perhaps as many as five loci with varying expression in different tissues and stages of development. The ERBA1 gene at 17q11.2 encodes ERBA alpha-1, ERBA alpha-2, and ERBA alpha-3, each produced by alternative splicing. All ERBA1 transcripts are coordinately expressed. The ERBA2 gene at 3p24.3 encodes ERBA beta-1 and a neighboring gene encodes ERBA beta-2. The TH receptor expressed in the mammalian CNS and most other tissues (except liver) is encoded by ERBA1. The receptor present in liver (the major TH-responsive organ) and some other tissues is encoded by ERBA2. Point mutations in the ERBA2 gene are associated with generalized resistance to thyroid hormone. 